\title{
STUDIES OF PULMONARY CARCINOGENESIS IN RODENTS FOLLOWING INHALATION OF TRANSURANIC COMPOUNDS*
}

\author{
C. L. Sanders and G. E. Dagle \\ Biology Department \\ Battelle \\ Pacific Northwest Laboratories \\ Richland, WA 99352
}

\section{MASTER}

\section{ABSTRACT}

The influence of absorbed radiation dose and its distribution on pulmonary carcinogenesis in rats were examined following inhalation of ${ }^{238} \mathrm{Pu}$ from crushed ${ }^{238} \mathrm{PuO}_{2}$ microspheres, ${ }^{238} \mathrm{PuO}_{2}$ or ${ }^{244} \mathrm{CmO}_{2}$ and following intratracheal instillation or inhalation of ${ }^{239} \mathrm{PuO}_{2}$. A more uneven dosedistribution (e.g. ${ }^{238} \mathrm{PuO}_{2}$ or ${ }^{239} \mathrm{PuO}_{2}$ ) favors squamous carcinoma induction at high doses, while adenocarcinoma induction is greater at lower doses or at all doses following a more even dose-distribution in the lung (e.g. ${ }^{238} \mathrm{Pu},{ }^{244} \mathrm{CmO}_{2}$ ). Squamous metaplasia and adenomatosis appeared to precede the development of squamous carcinoma and adenocarcinoma, respectively. Pulmonary hemangiosarcomas were found only after high doses

*This paper is based on research performed under United States Atomic Energy Commission Contract AT(45-1)-1830. 


\section{DISCLAIMER}

This report was prepared as an account of work sponsored by an agency of the United States Government. Neither the United States Government nor any agency Thereof, nor any of their employees, makes any warranty, express or implied, or assumes any legal liability or responsibility for the accuracy, completeness, or usefulness of any information, apparatus, product, or process disclosed, or represents that its use would not infringe privately owned rights. Reference herein to any specific commercial product, process, or service by trade name, trademark, manufacturer, or otherwise does not necessarily constitute or imply its endorsement, recommendation, or favoring by the United States Government or any agency thereof. The views and opinions of authors expressed herein do not necessarily state or reflect those of the United States Government or any agency thereof. 


\section{DISCLAIMER}

Portions of this document may be illegible in electronic image products. Images are produced from the best available original document. 
STUDIES OF PULMONARY CARCINOGENESIS IN RODENTS

FOLLOWING INHALATION OF TRANSURANIC COMPOUNDS

C. L. Sanders and G. E. Dagle

\section{INTRODUCTION}

Pulmonary deposited alpha emitting radionuclides have been shown to be potent carcinogens in the lung of experimental animals. Among these radionuclides; the transuranic oxides, ${ }^{238} \mathrm{PuO}_{2},{ }^{239} \mathrm{PuO}_{2}$, and ${ }^{244} \mathrm{CmO}_{2}$, constitute a potential health hazard to man associated with the nuclear industry. Lisco (1959) was the first to clearly describe the morphogenesis of pulmonary tumors in rats following deposition of ${ }^{239} \mathrm{PuO}_{2}$. He found three types of tumors induced by $\mathrm{PuO}_{2}$ : adenocarcinoma, squamous carcinoma and hemangioendòthelioma. Latter studies by Buldakov and Lyubchanskii (1970) with inhaled ${ }^{239} \mathrm{Pu}$ citrate and ${ }^{239} \mathrm{Pu}$ pentacarbonate in rats, demonstrated that the predominant lung tumors were adenocarcinomas at lower radiation doses to the lung and squamous carcinomas at higher radiation doses; they also observed several pulmonary hemangiosarcomas at higher doses.

This paper describes the development of lung tumors in rats following inhalation or intratracheal instillation of transuranic compounds. These compounds deliver a wide range of radiation doses to the lung and different spatialtemporal, dose-distribution patterns in the lung. It was shown that both the tumor type and incidence are influenced 
of inhaled ${ }^{239} \mathrm{PuO}_{2}$. These results demonstrate the importance of dose and dose-distribution on the development of pulmonary tumors from inhaled alpha emitters. 
THIS PAGE

\section{WAS INTENTIONALLY LEFT BLANK}


by the amount of deposited activity and by its distribution in the lung.

\section{$\underline{\text { METHODS }}$}

Wistar, SPF, female rats, about 70 days of age, were exposed in groups of 70 rats each to 4-5 dose levels of ${ }^{238} \mathrm{PuO}_{2},{ }^{239} \mathrm{PuO}_{2}$ or ${ }^{244} \mathrm{CmO}_{2}$. The ${ }^{244}$ curium oxide was a mixture of ${ }^{244} \mathrm{CmO}_{2}$ and ${ }^{244} \mathrm{Cm}_{2} \mathrm{O}_{3}$ but is designated as ${ }^{244} \mathrm{CmO}_{2}$ since the ratio of $\mathrm{Cm} / 0$ is not known. Exposures were by nose-only inhalation for a period of 30 minutes. The ${ }^{238} \mathrm{PuO}_{2}$ and ${ }^{239} \mathrm{PuO}_{2}$ aerosols exhibited count median diameters that ranged from $0.1 \mu \mathrm{m}$ to $0.3 \mu \mathrm{m}$, whereas the count median diameters of the ${ }^{238} \mathrm{Pu}$ or ${ }^{244} \mathrm{CmO}_{2}$ aerosols were only $0.02 \mu \mathrm{m}$ to $0.04 \mu \mathrm{m}$. Both ${ }^{238} \mathrm{Pu}$ and ${ }^{244} \mathrm{CmO}_{2}$ exhibited greater in vitro solubility than did $\mathrm{PuO}_{2}$ as tested by ultrafiltration through Visking tubing; the ultrafilterability of $\mathrm{PuO}_{2}$ being $<0.5 \%,{ }^{244} \mathrm{CmO}_{2}$ $2-3 \%$ and ${ }^{238} \mathrm{Pu} 70 \%$. Two additional groups of rats were given either an intratracheal instillation of $29 \mathrm{nCi}{ }^{239} \mathrm{PuO}_{2}$ in saline or only saline. The studies with inhaled ${ }^{238} \mathrm{Pu}$, derived from crushed ${ }^{238} \mathrm{PuO}_{2}$ microspheres in rats, have been previously published (Sanders, 1973). The experimentel design and initial deposition levels in the lung are shown in Table 1. About half the lung of each of 5 rats per group at one day after exposure and the lungs of all rats. which were autopsied when moribund or dead were fixed in $10 \%$ neutral buffered formalin, embedded in paraffin and sections 
stained with eosin and hematoxylin, some after processing for autoradiographic examination. The remaining half of lung tissue was analyzed for transuranic contents by scintillation counting. The data with inhaled ${ }^{238} \mathrm{PuO}_{2}$, ${ }^{239} \mathrm{PuO}_{2}$ or ${ }^{244} \mathrm{CmO}_{2}$ represents an interim report of a 1 ifespan study, emphasizing pathological alterations occurring in the lung for periods of up to two years postexposure.

\section{RESULTS AND DISCUSSION}

Lung Clearance - Inhaled ${ }^{238} \mathrm{PuO}_{2}$ or ${ }^{239} \mathrm{PuO}_{2}$ particles were cleared from the lung in a similar manner, with about $50 \%$ clearance of the initial alveolar deposition taken as the one day. lung burden in 30-50 days and a 225 day biological half-life for either isotope in the lung, thereafter (Figure 1). On1y $10-15 \%$ of initial alveolar deposited ${ }^{238} \mathrm{Pu}$ or ${ }^{24.4} \mathrm{CmO}_{2}$ remained in the lung at 50 days after inhalation with a 75-150 day biological half-life in the lung, thereafter (Figure 1). $\mathrm{PuO}_{2}$ particles were cleared mostly within alveolar macrophages (Sanders and Adee, 1970; Sanders, 1969) while ${ }^{244} \mathrm{CmO}_{2}$ or ${ }^{238} \mathrm{Pu}$, because of their greater solubility, were cleared from the alveoli mostly into the blood (Sanders, 1973).

Pulmonary Distribution - At one day after inhalation, both inhaled ${ }^{238} \mathrm{PuO}_{2}$ and ${ }^{239} \mathrm{PuO}_{2}$ particles were seen dispersed throughout the lung parenchyma, with a large range in the number of alpha tracks per star, indicative of a range of 
sizes of $\mathrm{PuO}_{2}$ particles. These particles were usually seen within macrophages or alveolar septae. The more soluble transuranics, ${ }^{244} \mathrm{CmO}_{2}$ or ${ }^{238} \mathrm{Pu}$, were initially distributed in the lung as single tracks or as loose aggregates of tracks mostly associated with the alveolar septae; stars, indicative of particles, were rare on autoradiograms (Figure 2). The little remaining ${ }^{244} \mathrm{CmO}_{2}$ or ${ }^{238} \mathrm{Pu}$ activity seen on autoradiograms at 1-10 months after exposure was evenly spread over the parenchyma as single tracks or as loose aggregates within macrophages or associated with hemosiderin-like pigment. in peribronchiolar, perivascular or subpleural regions of the lung. At 1-10 months after exposure, many of the ${ }^{238} \mathrm{PuO}_{2}$ or ${ }^{239} \mathrm{PuO}_{2}$ particles had found their way from macrophages into the alveolar septae, concentrating in subpleural regions of the lung (Figure 3), as well as in some peribronchiolar and perivascular regions of the lung. The pulmonary lymph nodes contained several percent of initially deposited ${ }^{238} \mathrm{PuO}_{2}$ or ${ }^{239} \mathrm{PuO}_{2}$, but little of ${ }^{244} \mathrm{CmO}_{2}$ or ${ }^{238} \mathrm{Pu}$.

The majority of the total radiation dose was delivered to the lung in a shorter period of time from ${ }^{244} \mathrm{CmO}_{2}$ or ${ }^{238} \mathrm{Pu}$ than from ${ }^{238} \mathrm{PuO}_{2}$ or ${ }^{239} \mathrm{PuO}_{2}$ particles. However, ${ }^{238} \mathrm{PuO}_{2}$ or ${ }^{239} \mathrm{PuO}_{2}$ particles were seen concentrated in subpleural regions of the lung, causing higher radiation doses to this region of the lung from ${ }^{238} \mathrm{PuO}_{2}$ or ${ }^{239} \mathrm{PuO}_{2}$. particles than were seen following ${ }^{244} \mathrm{CmO}_{2}$ or ${ }^{238} \mathrm{Pu}$. Thus the amount of 
radiation dose per $\mu \mathrm{Ci}$ of transuranic deposited in the lung was significantly less but more evenly distributed in the lung for inhaled ${ }^{244} \mathrm{CmO}_{2}$ or ${ }^{238} \mathrm{Pu}$. than for ${ }^{238} \mathrm{PuO}_{2}$ or ${ }^{239} \mathrm{PuO}_{2}$ particles.

Development of Pulmonary Tumors - Plutonium dioxide particles concentrated in subpleural regions of the ling in the highest dose groups, produced a severe radiation pneumonitis with marked thickening and consolidation of the alveolar septae by connective tissue (Figure 3 ). Plutonium particles became entrapped within fibrotic subpleural areas within a few months after inhalation. Within three months after inhalation isolated islands of metaplastic squamous cells were found proliferating within these fibrotic areas, usually where the $\mathrm{PuO}_{2}$ particle concentration was the greatest (Figure 3). Squamous cells then began to proliferate and move towards the zones of lower $\mathrm{PuO}_{2}$ concentration in the more central parts of the lung lobes, showing evidence more of carcinoma in situ, a histologic interim stage between squamous metaplasia and squamous carcinoma. Squamous carcinomas exhibited varying degrees of differentiation. Those squamous carcinomas with abundant keratin tended to take up a large part of the lobe in which they originated, whereas less differentiated tumors with little or no keratin formation, tended to spread to all lobes of the lung. These latter squamous carcinomas were seen growing into the pleural cavity and in the pulmonary 
lymphatics. The development of squamous carcinoma from subpleural concentrations of $\mathrm{PuO}_{2}$ particles was similar to that seen in the rat following "hot spots" of $\mathrm{PuO}_{2}$ particle concentration after intrapulmonary injection of ${ }^{2 \cdot 39} \mathrm{PuO}_{2}$ (Sanders and Park, 1972).

Rats exposed to high levels of ${ }^{238} \mathrm{Pu}$ or ${ }^{244} \mathrm{CmO}_{2}$ or to the lower dose levels of $\mathrm{PuO}_{2}$ did not exhibit marked subpleural fibrosis or squamous metaplasia. Rats exposed to the highest amount of ${ }^{244} \mathrm{CmO}_{2}$ exhibited a generalized radiation pneumonitis with moderate thickening of the alveolar septae and an accumulation of protein and fluids in the alveolar air spaces; rats living longer than six months after inhalation of ${ }^{24.4} \mathrm{CmO}_{2}$ exhibited only minimal to moderate alveolar septal thickening due to radiation pneumonitis.

In contrast to squamous metaplasia, alveolar adenomatous metaplasia or adenomatosis was seen in all but control and the lower deposition level groups of rats exposed to all transuranics (Figure 4). Areas of adenomatosis were more likely to be found in subpleural regions of $\mathrm{PuO}_{2}$ particle concentration, although the association was much less apparent than it was with squamous metaplasia formation. Pulmonary adenocarcinomas varied from small, well-circumscribed, papillary' ' well-differentiated tumors to undifferentiated tumors that were metastic throughout the lung, in the pleural cavity and in pulmonary lymph nodes (Figure 4). 
Four hemangiosarcomas were seen in rats which had inhaled ${ }^{239} \mathrm{PuO}_{2}$ and none in any of the other groups. These tumors were characterized by irregular islands of sarcomatous tumor cells forming small to large cavities filled with red blood cells (Figure 4).

Lung Tumors and Dose and Dose Distribution - There was a fairly clear temporal relationship between the development of squamous metaplasia and subsequent appearance of squamous carcinoma, and the development of adenomatosis and the subsequent: appearance of adenocarcinoma. Thus; both squamous metaplasia and adenomatosis appeared to be preneoplastic stages in developing squamous carcinoma or adenocarcinoma, respectively, since their incidence preceded and paralleled the incidences of frank carcinomas.

Squamous metaplasia and squamous carcinoma, were seen only in rats with the highest levels of ${ }^{238} \mathrm{PuO}_{2}$ or ${ }^{239} \mathrm{PuO}_{2}$ deposition with the exception of one squamous carcinoma in a rat that had inhaled ${ }^{238} \mathrm{Pu}$ (Table 1). The more uneven dose distribution of ${ }^{238} \mathrm{PuO}_{2}$ or ${ }^{239} \mathrm{PuO}_{2}$ particles with physiological concentration of particles in the subpleural lymphatics, greatly favored the induction of squamous carcinoma at high initial lung depositions, while adenocarcinoma induction was greatly favored by a more even dose distribution as was seen. with inhaled ${ }^{238} \mathrm{Pu}$ or ${ }^{244} \mathrm{CmO}_{2}$. For either ${ }^{238} \mathrm{PuO}_{2}$ or ${ }^{239} \mathrm{PuO}_{2}$, more squamous carcinomas were seen at radiation doses to lung 
of approximately greater than about 1000 rads, corresponding to an initial alveolar deposition greater than $50 \mathrm{nCi}{ }^{238} \mathrm{PuO}_{2}$ of ${ }^{239} \mathrm{PuO}_{2}$, with adenocarcinomas being predominant at lower doses of ${ }^{238} \mathrm{PuO}_{2}$ or ${ }^{239} \mathrm{PuO}_{2}$. Hemangiosarcomas were seen only at the two highest dose levels of ${ }^{239} \mathrm{PuO}_{2}$. These interim results with inhaled ${ }^{238} \mathrm{PuO}_{2}$ or ${ }^{239} \mathrm{PuO}_{2}$ are somewhat similar to observations made by Buldakov and Lyubchanskii (1970) in rats following inhalation of ${ }^{239} \mathrm{Pu}$ citrate or ${ }^{239} \mathrm{Pu}$ pentacarbonate. Both total dose delivered to lung and its distribution in the lung influence the induction of adenocarcinoma, squamous carcinoma and hemangiosarcoma in the ling of rats following inhalation of transuranic compounds, with adenocarcinomas occurring more frequently following inhalation of "soluble" or more monomeric transuranic compounds and squamous carcinomas and hemangiosarcomas occurring more frequently following inhalation of "insoluble" particulate or more polymeric transuranic compounds. 


\section{LITERATURE REFERENCES}

L. Lisco, H.: Autoradiographic and histologic studies in radiation carcinogenesis of the lung. Lab. Invest. $\underline{8}$, $162-170$ (1959).

?. Buldakov, L. A. and Lyubchanskii, E. R.: Experimental basis for maximum allowable load (MAL) of Pu-239 in the human organism, and maximum allowable concentration (MAC) of $\mathrm{Pu}-239$ in air at work locations. Original source unknown. ANL-TRANS-864 (1970).

1. Sanders, C. L. and Adee, R. R.: Ultrastructural localization of inhaled ${ }^{239} \mathrm{PuO}_{2}$ particles in alveolar epithelium and macrophages. Health Physics 18, 293-295 (1970).

r. Sanders, C. L.: The distribution of inhaled plutonium239 dioxide particles within pulmonary macrophages. Arch. Environ. Health 18, 904-912 (1969).

i. Sanders, C. L.: Carcinogenicity of inhaled plutonium238 in the rat. Radiation Research 56, 540-553 (1973).

i. Sanders, C. L. and Park, J. F.: Pulmonary distribution of alpha dose from ${ }^{239} \mathrm{PuO}_{2}$ and induction of neoplasia in rats and dogs, p. 489-498. In: W. H. Walton (ed.) International Symposium on Inhaled Particles III, Vol. 1. Oxford: Pergamon Press (1971). 


\section{FIGURE LEGEND}

Figure 1. Alveolar retention of inhaled transuranic compounds.

Figure 2. Autoradiograms of lung at one day after inhalation of transuranic compounds. Upper left: ${ }^{238} \mathrm{PuO}_{2}$, two week exposure. $\mathrm{x} 220$ Upper right: ${ }^{239} \mathrm{PuO}_{2}$, two week exposure. X220 Lower left: ${ }^{238} \mathrm{Pu}$, three day exposure. $\mathrm{X} 525$ Lower right: ${ }^{244} \mathrm{CmO}_{2}$, three day exposure. X220

Figure 3. Autoradiograms of lung at 6-8 months after inhalation of ${ }^{238} \mathrm{PuO}_{2}$. Two week exposure of autoradiograms. Upper left: Subpleural $\mathrm{PuO}_{2}$ concentration and severe radiation pneumonitis. X220 Upper right: Squamous metaplasia in subpleural area of high $\mathrm{PuO}_{2}$ concentration. X220 Lower left: Early . squamous carcinoma developing from subpleural area of $\mathrm{PuO}_{2}$ concentration. $\mathrm{X} 54$ Lower right: Squamous carcinoma surrounding a $\mathrm{PuO}_{2}$ particle. X 220

Figure 4. Adenomatosis, adenocarcinoma and hemangiosarcoma in the lung after inhalation of ${ }^{239} \mathrm{PuO}_{2}$. Upper left: Adenomatosis at 293 days after inhalation. X220 Upper right: Papillary adenocarcinoma at 567 days after inhalation. X560 Lower left: Undifferentiated adenocarcinoma at 619 days after inhalation. X220 Lower right: Hemangiosarcoma at 560 days after inhalation. X560 


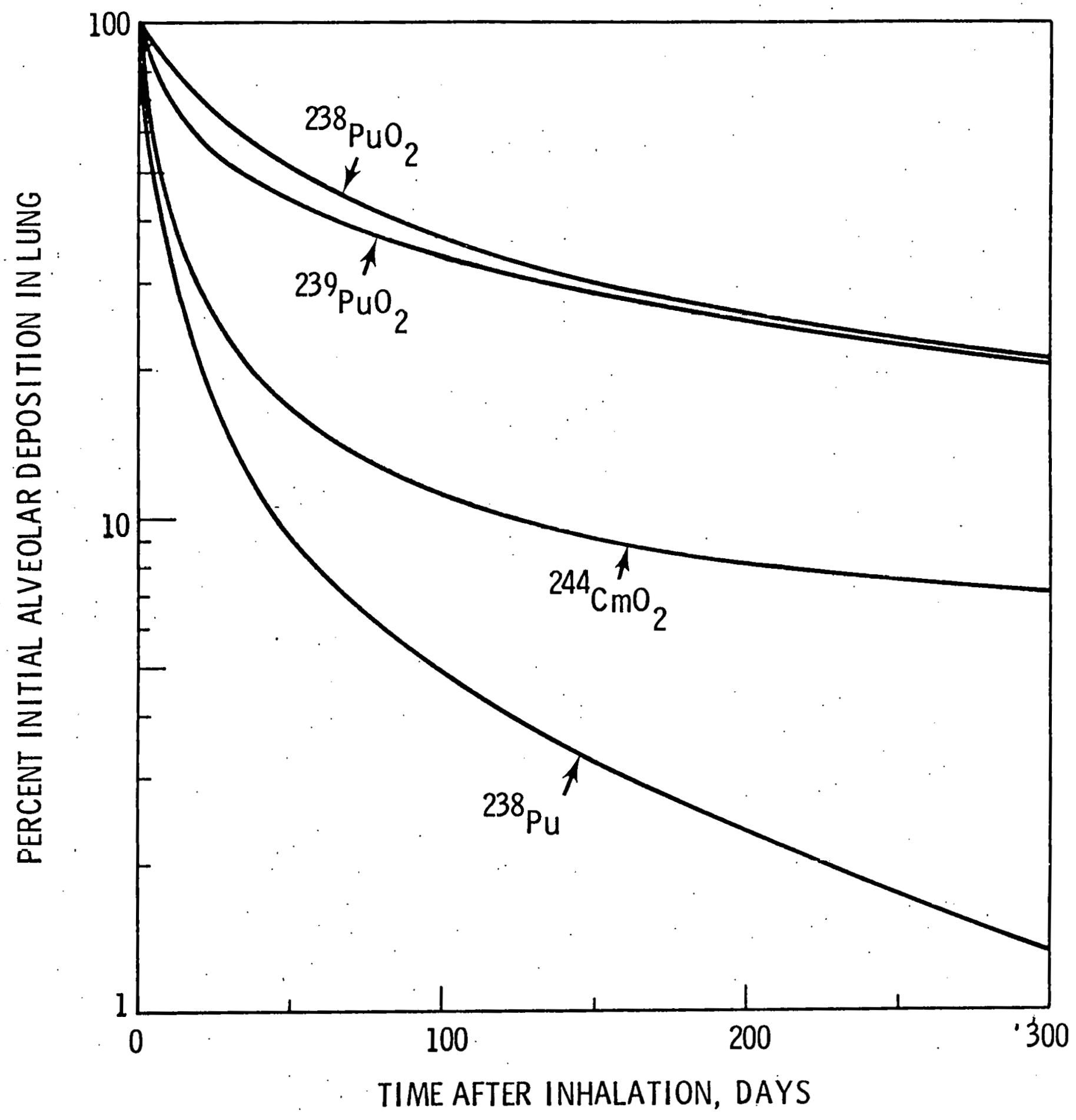



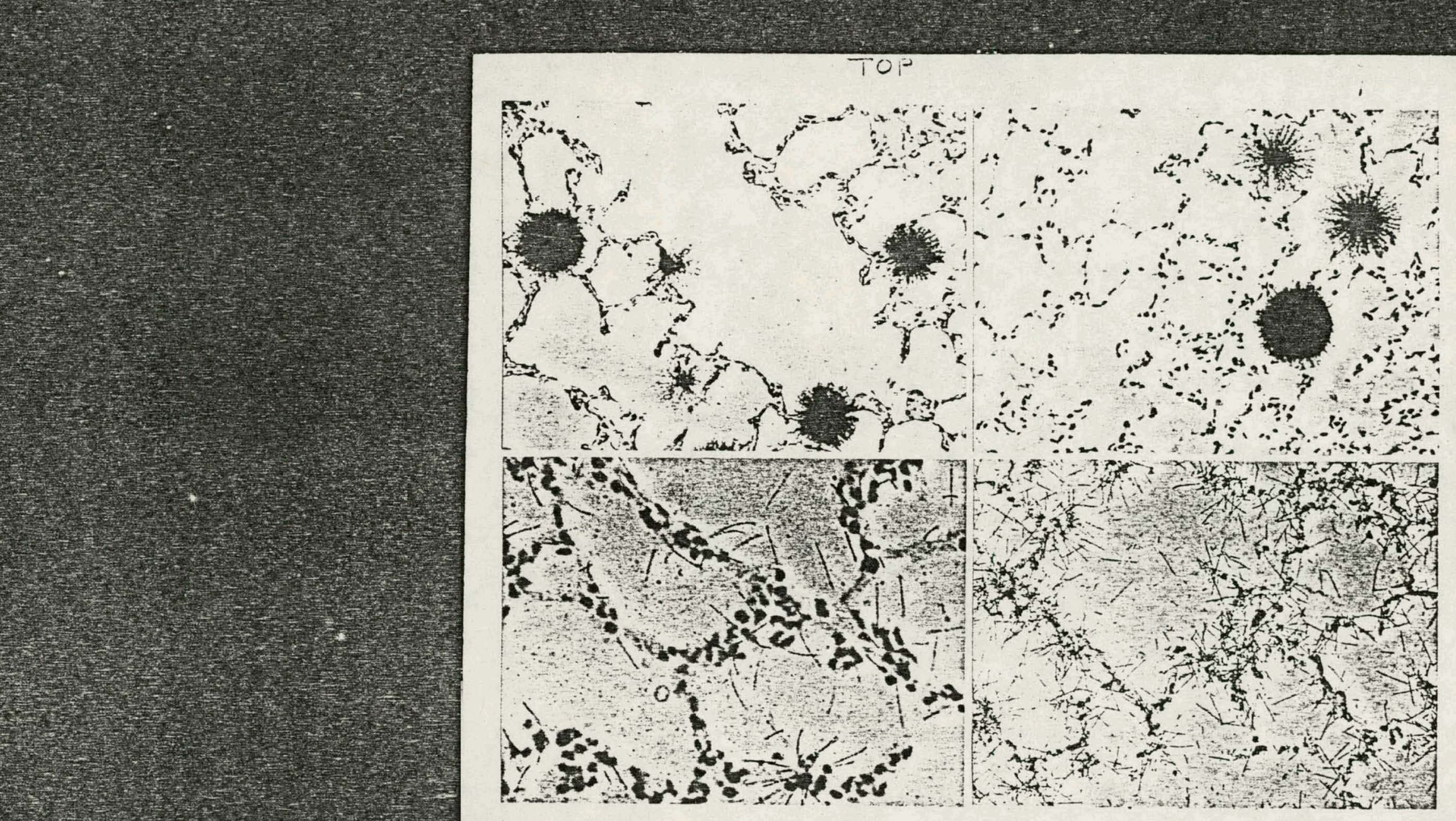

(5) in 4 trita दो

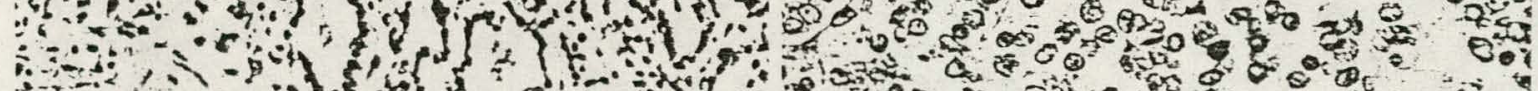
ind $\because$ on W

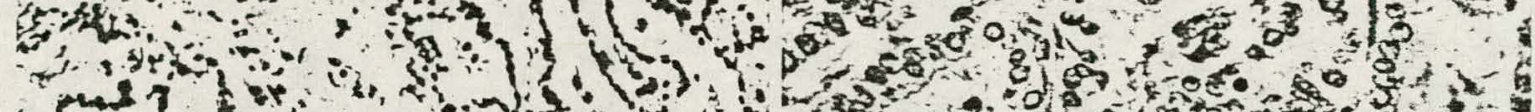

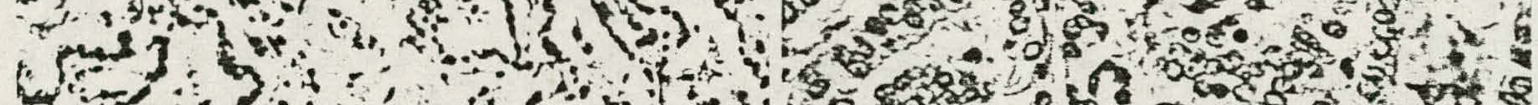

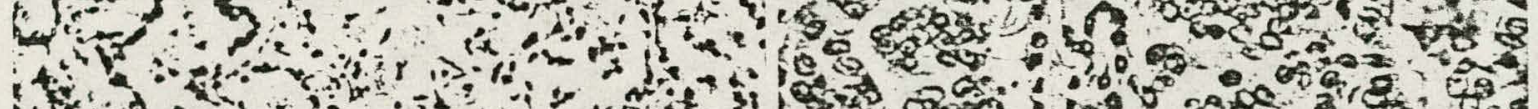

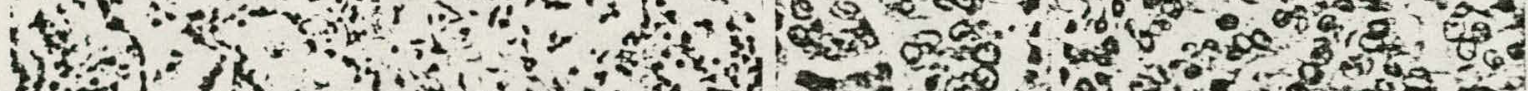

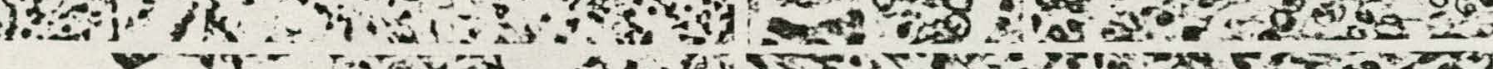

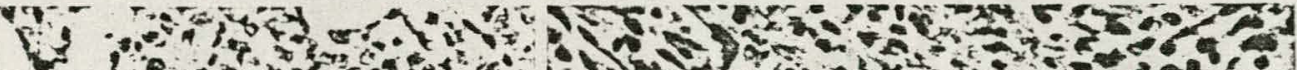

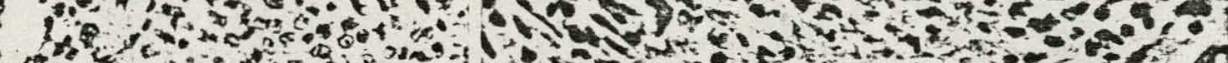

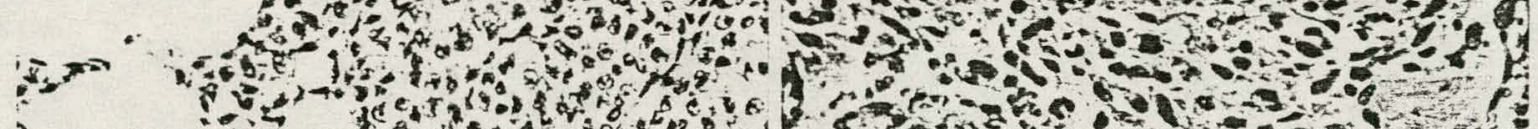
5.

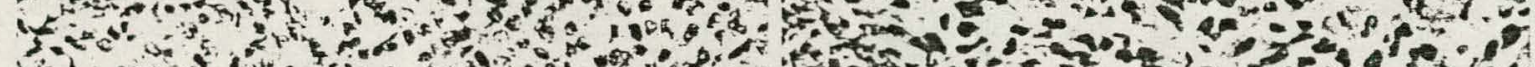

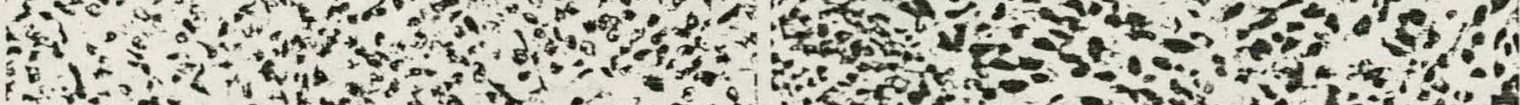

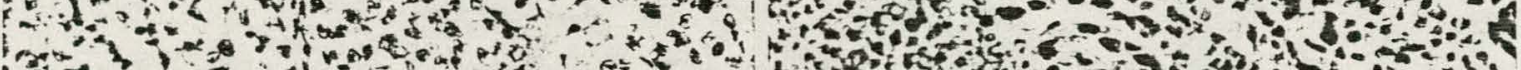

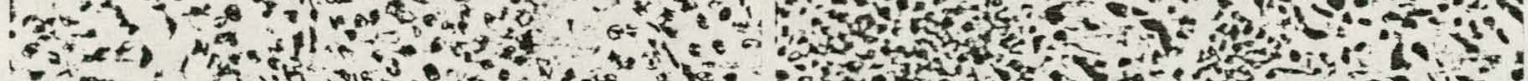

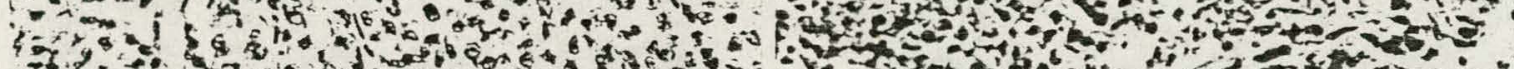

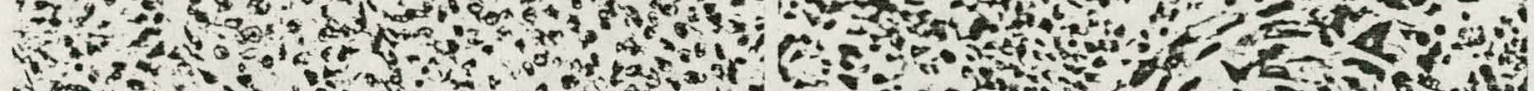
ond

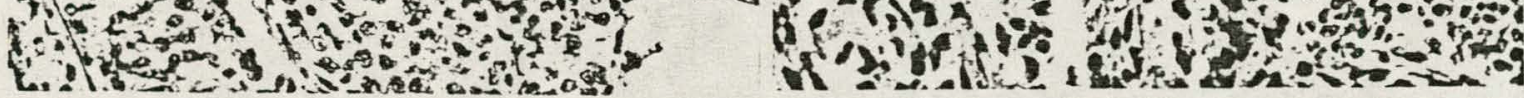


